\section{Analisa Stabilitas Perkuatan Tebing Sungai Pada Hulu Sungai Amandit}

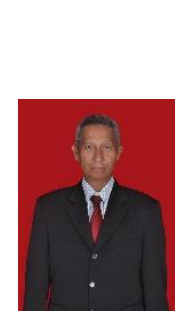

\section{Mukhriansyah.}

Mukhriansyah lahir di Banjarmasin, Kalimantan Selatan pada 13 mei 1963 anak ke empat dari delapan bersaudara dari ayah bernama Muchlan Tarmidi dan ibu bernama Djalimah adalah seorang direktur dan komisaris di beberapa perusahaan lokal dalam bidang konstruksi, pendidikan terakhir adalah sarjana Universitas Lambung Mangkurat Banjarmasin dengan program studi Teknik Sipil. buletinppi@ulm.ac.id
Proses gerusan terjadi karena adanya perubahan pola aliran yang melewati suatu penampang sungai sehingga partikel-partikel dasar sungai akan terangkut dan ditransportasikan dari daerah asalnya selapis demi selapis dan proses tersebut terjadi berulang-ulang sampai mencapai suatu keseimbangan dasar sungai yang baru. Kondisi sungai amandit khususnya di desa malutu sebelah hilir bendung amandit tebing bagian kiri terjadi longsong karena gerusan air terutama pada belokan sungai. Oleh sebab itu, maka di adakannya pekerjaan pembangunan pengendalian erosi dan proteksi sungai amandit di kabupaten Hulu Sungai Selatan. Pembangunan pengendalian erosi berupa kubus beton sebagai pelindung kaki dinding penahan dan proteksi sungai berupa dinding penahan beton dengan counterfort sebagai perkuatan tebing

www.buletinppi.ulm.ac.id

\section{Pendahuluan}

Sungai memeliki peranan yang sangat penting bagi kehidupan manusia khususnya didaerah hulu dari sungai. Sungai seringkali dimanfaatkan sebagai sarana transportasi, sumber air baku, dan sebagainya.

Sungai merupakan saluran yang terbentuk secara alami yang mempunyai fungsi seperti saluran. Air yang mengalir dapat mengakibatkan proses penggerusan pada tanah dasar. Gerusan yang terjadi secara terusmenerus akan membentuk lubang-lubang gerusan di dasar sungai. Gerusan tersebut terjadi karena adanya pengaruh morfologi sungai salah satu contohnya berupa tikungan atau penyempitan sungai. Aliran yang terjadi pada sungai juga disertai proses penggerusan dan endapan sedimen. Morfologi sungai merupakan salah satu faktor yang menentukan dalam proses terjadinya gerusan. Hal ini disebabkan aliran sungai mempunyai permukaan bebas, sehingga kondisi tersebut cenderung berubah seiring waktu, kedalaman aliran, debit air, kemiringan dasar, dan permukaan bebas itu sendiri.

Aliran sungai bisa menyebabkan erosi. Erosi yang sering terjadi di sungai sering kali terjadi pada bagian tebing sungai. Erosi ini terjadi akibat pengerusan tebing sungai oleh air yang mengalir dari bagian atas tebing atau hantaman aliran atau arus sungai yang kuat pada belokan sungai. Oleh karena itu perlu adanya perlindungan terhadap tebing sungai agar tidak terjadi gerusan atau erosi terhadap tebing. Perlindungan tersebut dapat berupa riprap, bronjong, dinding beton dan sebagainya.

Sehingga dilaksankanlah pekerjaan pembangunan pengendali erosi dan proteksi sungai amandit yaitu pelaksanaan pekerjaan proteksi tebing sungai pada belokan sungai amandit yang terjadi longsoran atau erosi pada tebing akibat gerusan aliran sungai disebabkan arus sungai yang deras menghantam pada tebing di belokan sungai tersebut. Pelaksanaan pekerjaan ini dilakukan dengan pembuatan dinding penahan beton untuk menahan gerusan air yang terjadi pada tebing sungai dan pekerjaan kubus beton untuk mengurangi hantaman arus sungai terhadap dinding beton yang diletakan di depan dinding penahan beton tersebut.

\section{Hasil Kerja}

Sungai amandit merupakan sungai yang mengalir melewati desa malutu kecamatan padang batung, aliran sungainya berasal dari mata air dan limpasan air hujan. Aliran sungai amandit dimulai dari hulu di kecamatan loksado kemudian bermuara di sungai antasan belimau di kecamatan simpur dan sungai tirtahahalayung di kecamatan kandangan.

Kondisi sungai amandit khususnya di desa malutu sebelah hilir bendung amandit tebing bagian kiri terjadi longsong karena gerusan air terutama pada belokan sungai. Sehingga jalan akses menuju bendung dan daerah sekitarnya terganggu. Karena setengah badan jalan longsor dan hanya bisa dilalui kendaraan roda dua dan hampir mengenai rumah masyarakat sekitar. Seperti terlihat pada Gambar 1.

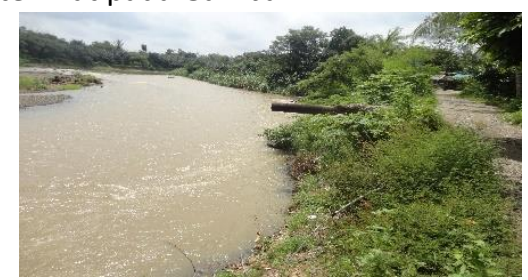

Gambar 1. Kondisi Tebing Sungai Amandit yang Longsor 
Perkuatan lereng/revetment merupakan struktur perkuatan yang ditempatkan ditebing sungai untuk menyerap energi air yang masuk guna melindungi suatu tebing alur sungai atau permukaan lereng tanggul tehadap erosi dan limpasan gelombang (overtopping) ke darat dan secara keseluruhan berperan meningkatkan alur sungai atau tubuh tanggul yang dilindungi (Habibi Tengku ; 2016).

Bangunan revetment biasanya terbuat dari pasangan batu, beton, tumpukan buis beton, turap beton atau turap baja, dan tumpukan batu. Yang sering dijumpai dalam pelaksanaan pekerjaan perkuatan lereng menggunakan dinding beton, turap beton atau turap baja, bronjong dan pasangan batu.

Dalam pelaksanaan pekerjaan pembangunan pengendalian erosi dan proteksi sungai amandit di kabupaten Hulu Sungai Selatan, untuk proteksi sungai dilakukan dengan perkuatan tebing yaitu pembuatan dinding penahan. Konstruksi perkuatan tebing menggunakan dinding penahan beton dengan counterfort setebal $20 \mathrm{~cm}$ tiap jarak $3 \mathrm{~m}$.

Dinding counterfort serupa dengan dinding kantiliver, tetapi pada dinding tersebut digunakan untuk konsol yang panjang atau untuk tekanantekanan yang sangat tinggi di belakang dinding dan mempunyai pertebalan di belakang yang mengikat dinding dan dasar bersama-sama, yang dibangun pada interval-interval sepanjang dinding untuk mengurangi momen-momen lentur dan geser di belakang dinding. (captain piezocone ; 2012). Dinding counterfort digunakan untuk menahan longsoran tanah akibat terjadinya erosi pada tebing sungai amandit. Pemilihan dinding counterfort ini dikarenakan paling sesuai dengan kondisi sungai amandit yang berarus deras dan tebing sungai yang tinggi.

Dasar sungai selalu mengalami perubahan bentuk dan elevasinya. Hal ini disebabkan karena sungai selalu berusaha mencapai keseimbangan dinamisnya. Pada dasar sungai terjadi proses penggerusan dan pengendapan akibat adanya karakteristik aliran. Dua proses tersebut menyebabkan bentuk dan elevasi dasar sungai selalu mengalami perubahan untuk jangka waktu tertentu.

Proses gerusan terjadi karena adanya perubahan pola aliran yang melewati suatu penampang sungai sehingga partikel-partikel dasar sungai akan terangkut dan ditransportasikan dari daerah asalnya selapis demi selapis dan proses tersebut terjadi berulang-ulang sampai mencapai suatu keseimbangan dasar sungai yang baru.

Menurut Raudkivi dan Ettema (1982) dalam Gunawan (2006:10) ada tiga gerusan yaitu:

1. Gerusan umum di alur sungai. Gerusan ini tidak berkaitan sama sekali ada atau tidaknya bangunan sungai.
2. Gerusan lokalisir di alur sungai. Gerusan terjadi karena meyempitnya alur sungai sehingga aliran menjadi terpusat.

3. Gerusan lokal di sekitar bangunan. Gerusan terjadi karena pola aliran lokal di sekitar bangunan sungai.

Peristiwa ke tiga jenis gerusan di atas dapat terjadi bersamaan tetapi pada lokasi yang berbeda. Selanjutnya ada beberapa fenomena yang berhubungan dengan gerusan (larsen, 1952) dalam Sucipto (2004:34) yaitu:

1. Besarnya gerusan akan sama dengan selisih antara jumlah material yang ditranspor keluar daerah gerusan dengan jumlah material yang masuk ke dalam daerah gerusan.

2. Besarnya gerusan akan berkurang apabila penampang basah di daaerah gerusan bertambah.

3. Untuk suatu kondisi aliran akan ada suatu keadaan gerusan yang disebut gerusan batas, besarnya akan asimtot terhadap waktu.

Faktor yang mempengaruhi gerusan pada sungai sebagai berikut:

1. Tinggi muka air sungai.

2. Kemiringan dasar sungai.

3. Debit aliran sungai.

4. Jenis butiran dasar sungai dan jenis butiran yang dibawa aliran.

5. Penampang sungai dan bangunan yang ada.

Selain pekerjaan dinding penahan tanah pada pekerjaan pembangunan pengendalian erosi dan proteksi sungai amandit di kabupaten Hulu Sungai Selatan terdapat juga pekerjaan kubus beton dengan ukuran $70 \times 70 \times 70 \mathrm{~cm}$ sebagai pelindung kaki dinding penahan untuk mengurangi arus sungai yang bisa menyebabkan kerusakan tebing pada tikungan sungai amandit.

Kondisi sungai amandit setelah pelaksanaan pembangunan pengendalian erosi dan proteksi sungai. Seperti terlihat pada Gambar 2 berikut.

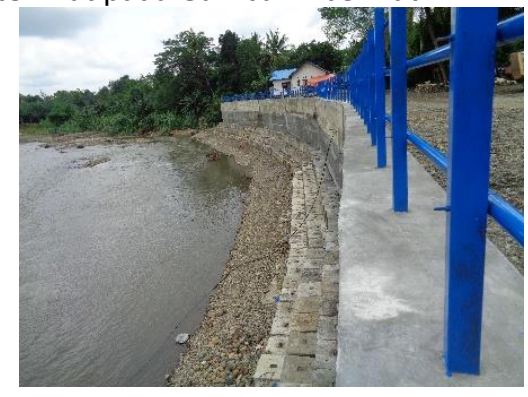

Gambar 2. Kondisi Sungai Amandit Setelah Pelaksanaan Pembangunan Pengendalian Erosi dan Proteksi Sungai 


\section{Kesimpulan}

Berdasarkan hasil analisa dari pelaksanaan pekerjaan pembangunan pengendalian erosi dan proteksi sungai amandit di kabupaten Hulu Sungai Selatan dapat disimpulkan dikerjakan pembangunan pengendalian erosi berupa kubus beton sebagai pelindung kaki dinding penahan dan proteksi sungai berupa dinding penahan beton dengan counterfort sebagai perkuatan tebing.

\section{Ucapan Terimakasih}

Syukur Alhamdulillah senantiasa saya panjatkan kehadirat Allah SWT. Yang memiliki keistimewaan dan pemberian segala kenikmatan besar, baik nikmat iman, kesehatan dan kekuatan dalam menyusun buletin ini. Selamat dan salam senantiasa tercurahkan kepada sayidina Muhammad SAW, keluarga, dan para sahabatNya dan penegak sunnah-Nya sampai kelak akhir zaman.

Pada kesempatan ini saya menyampaikan rasa terimakasih yang sebesar-besarnya dan penghargaan yang setinggi-setingginya kepada :

1. Kepala program studi Program Profesi Insinyur Bapak Prof. Dr. Ir. Rusdi HA, M.Sc, IPU.

2. Seluruh dosen dan staf program studi Program Profesi Insinyur.

3. Sahabat-sahabatku sejurusan (Angkatan Pertama program studi Program Profesi Insinyur).

Terimakasih kepada ayah dan ibu atas doa dan dukungannya. Terimakasih juga kepada isteri dan anakanak saya yang telah membantu menyelesaikan buletin ini.

\section{Referensi}

1 Gunawan, H. A. 2006. Pengaruh Lebar Pilar Segiempat Terhadap Perilaku Gerusan Lokal. Skripsi. Semarang : UNNES

2 H. Tengku. 2016. Tipe-tipe struktur pelindung tebing sungai, Academia.

3 Piezocone captain. 2012. Dinding penahan tanah dan tekanan tanah lateral. Blogspot.

4 Sucipto dan Nur Qudus. 2004. Analisis Gerusan Lokal di Hilir Bed Protection. Jurnal Teknik Sipil dan Perencanaan. Nomer 1 Volume 6. Januari 2004. Semarang. UNNES 